\title{
Rewriting the Feminine Construction of a Nation in Comfort Woman by Nora Okja Keller
}

\section{Chow Sheat Fun}

Literature Section, School of Distance Education, Universiti Sains Malaysia, 11800 Penang, Malaysia

\begin{abstract}
This essay highlights the way Keller's novel, Comfort Woman (1997) explores the connection between women's sexual bodies, colonialism and Korean nationalism. Through the resistance of heroic women characters against patriarchal definitions and feminization of a colonized nation, Keller narrates subversive feminist resistance to humiliating inscriptions of patriarchy and colonialism onto the sexual bodies of women. The text is closely analysed using tools of literary devices, in particular, subversive strategies and the idea of silences as a tool and a theme to convey the unspoken and the unspeakable. Soon Hyo's passive silences as a comfort woman in the comfort camps and her transformation later to paranormal articulations as a shaman is interpreted as powerful forms of resistance against patriarchy's inscription upon her body. Her silent passivity, re-interpreted as a form of active resistance becomes more meaningful as she wrestles back the identities and recognition for the thousands of comfort women that would otherwise be forgotten. Comfort Woman inquires into the links between languages, silences and subjectivity, colonial domination and Korean nationalism, sexuality and nation, resisting any attempts at separating the links. Keller invoked the power of performance and silences in the form of "strange" articulations and tropes which were culturally specific as subversive means of re-telling her story and inscribing new meanings onto women's sexual bodies, thus rewriting the feminine constructions of a nation.
\end{abstract}

Keywords: Comfort woman, national identity, passivity, rewriting, sexual bodies, silences, subversive

ARTICLE INFO

Article history:

Received: 14 July 2020

Accepted: 07 September 2020

Published: 25 December 2020

DOI: https://doi.org/10.47836/pjssh.28.4.28

E-mail address:

sfchow@usm.my feminine resistance

\section{INTRODUCTION}

Historically, Japanese war crimes against women in China, Korea and elsewhere have long been documented. The brutal and 
horrific rapes that occurred in Nanking in December 1932 had caused concern around the world. To prevent further atrocities, reduce sexually transmitted diseases and ensure a steady supply of prostitutes to satisfy Japanese soldiers' sexual appetites, Emperor Hirohito ordered the military to establish "comfort stations".

Colonial Korea was part of Imperial Japan since 1894 and this rationale was used to justify Korean women contributing to the war as 'volunteer corps'. According to Yang (1997), since colonial women's bodies were not clearly located in the position of enemy, they were treated as a form of "military supply" (Yang, 1997, p. $65)$, seen as necessary for the protection of the Japanese soldiers from venereal disease.

When Japan began to lose the war, many of these women were killed in unimaginably cruel ways to prevent them from giving evidence against the war crimes committed on them. As a result, there has been silence surrounding the comfort women's tales and existence for 50 years, both in Japan and in Korea and other places (Indonesia, China, Philippines), until some survivors of these camps identified themselves publicly as former comfort women in the early 1990s, demanded apologies and compensations ${ }^{1}$, breaking the long official silence regarding the systemized rape of colonized women during World War II.

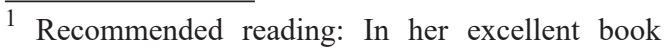
entitled The Comfort Women: Sexual Violence and Postcolonial Memory in Korea and Japan, C. S. Soh (2008) probed the historical issue of Comfort Women and the atrocities of sexual slavery perpetrated by the Japanese army during World War II.
}

\section{METHODS}

Textual analysis was applied to written historical and literary texts to interpret and investigate nuances, ideas and themes related to the issue of comfort women during World War II. The interpretation of the text is rooted within the historical, social and cultural understanding of the place and time in which the events took place. The selected literary text reflecting the relevant historical events was closely analysed using tools of literary devices, in particular, subversive strategies and the idea of silences as a tool and a theme to convey the unspoken and the unspeakable. This is done in order to deepen understanding of authorial intentions and strategies.

\section{RESULTS}

This essay portrays the ways Keller in Comfort Woman demonstrates resistance to humiliating perception with regard to Korean women's sexuality. Through various subversive techniques, Keller contests the feminization of Korea and rewrites the feminine construction of a colonized nation by creating women characters who proclaim themselves as the nation itself.

\section{DISCUSSION}

\section{Women's Sexuality, Colonialism and Korean Nationalism}

Rape is often employed as a weapon of war, used as a method of torturing and destroying, signifying the subjection of one nation to another. Rapes that occur between ethnic and/or religious groups 
in times of war signify that women's bodies are the possession of men. Rape symbolizes possession of the enemy's property (Yang, 1997) and institutionalized rape is a deliberate act of conquest, which causes national humiliation and shame.

This sense of humiliation and the fear of emasculation cause the comfort women issue to be viewed as a national embarrassment and relegated to just "woman's problem" silenced from collective memory until 1991. The women are living symbols that remind the nation of its "patriarchal weakness and paternal failure"- the failure of Korean men to protect the lives and bodies of their wives, daughters and sisters (Yang, 1998, p. 94).

In Korea, this humiliation and shame form core national sentiments surrounding the topic of comfort women. The representation of sexually violated Korean women as "damaged" and "disgraceful" results in subordination and silencing of the former comfort women (Kim, 1997, p. 92).

According to Duncan, some Korean men are angry that Korean women's sexuality, regarded as rightfully belonging to them - has been seized by Japanese soldiers, thereby "robbing Korean men" (Duncan, 2004, p. 180). The national humiliation associated with being "robbed" is reflected in a letter, written in 1992 by a Korean man who claimed that the history of Japanese colonization and the comfort woman system "amounts to an act in which the Japanese throw their dirty sperm bucket into our Korean people's face" (Yang, 1998, p. 130). Yang rightly pointed out that his reader's letter thus exemplified that males were the only subjects involved in questions of nation and sexuality. The nation is gendered. Women's sexuality is nationalized. "Nation is equated with male subject position, and women's sexuality is reified as property of the masculine nation" (Yang, 1998, p. 130).

\section{Giving Voice to the Voiceless}

The silences of the comfort women were given a voice in Nora Okja Keller's (1997) Comfort Woman, winner of the 1998 American Book Award. Keller had felt the intense need to exorcise the nightmares which had been haunting her when she first attended a talk given by a former Korean comfort woman, Keum Ja Hwang.

Comfort Woman is the fictional story of one woman, as shown in the singular noun of the title. Keller said, "I can only speak from this one body, this one mind, this one life's experiences" ${ }^{\prime 2}$ yet she may have inevitably rendered the private public by her imagined narration of the gruesome experiences of the women in the comfort camps during World War II. In order to re-narrate history, Keller kept the narrative as close as possible to the autobiographies of the former comfort women as she reconstructed patriarchal ideas of women's sexuality and showed the transcendence of Soon Hyo over her traumatic past.

Comfort Woman is an unsettling tale that interweaves the voices of a Korean American mother, Soon Hyo and her daughter, Beccah. Soon Hyo is haunted

\footnotetext{
${ }^{2}$ Keller, N. O. (1997). A penguin readers guide to Comfort Woman. In Comfort Woman (p. 3). New York, USA: Penguin Books.
} 
by her harrowing experience as a comfort woman during World War II; an experience so agonizing it caused her to live the rest of her life straddling between the world of the living and the dead and the spirits, barely living nor dead. The novel focuses on the fraught relationship between mother and daughter. The complex structure shifts back and forth in time and space, from Soon Hyo's childhood in Korea, to the World War II military camps, to Hawaii in the 1980s and 90s where Soon Hyo grapples with her traumatic past.

Through the resistance of Soon Hyo against patriarchal definitions, Keller narrated subversive feminist resistance to humiliating inscriptions of patriarchy and colonialism onto the sexual bodies of women. Soon Hyo's passive silences as a comfort woman and her transformation to paranormal articulations later as a shaman can be interpreted as powerful forms of resistance against patriarchy's inscription upon her body. Her silent passivity, reinterpreted as a form of active resistance became more meaningful as she wrestled back the identities and recognition for the thousands of comfort women that would otherwise be forgotten.

Keller invoked the power of silences in the form of "strange" articulations and tropes which were culturally specific as subversive means of re-telling her story and inscribing new meanings onto women's sexual bodies, hence re-creating them as national heroines, transcending their victim status. The dominant idea of this article is that "passivity" can be a form of active resistance.

\section{Narrative Technique - Conflicting Parallels and Paradoxes}

Keller began the novel by establishing a setting in which mysticism ruled and continued to dominate throughout the novel. Beccah's narration of the direct 'confession' of her mother to her father's murder at the beginning of the novel was casual, matterof-fact and dispassionate, during an activity of preparing a meal to honour his memory. The loaded statement "I killed your father" (Keller, 1997, p. 1), gave no hint to the themes that were possibly contained in the simple declaration. The 'killing' of Beccah's father was symbolical of Soon Hyo's release from patriarchal and sexual domination and condemnation and her subsequent union with the spiritual world which Beccah could not comprehend. The seemingly insignificant 'confession' held the key and the defining moment of Soon Hyo's life when after years of oppression, like Induk, she finally forsook all control as she danced in the rain in front of her helpless, pleading husband on a night Beccah could faintly recall.

Beccah's skepticism and fear were not towards the confession per se but she thought her mother was slipping into one of her trances. As Beccah was unable to differentiate between the mystic, spiritual part of her mother and the physical, human side of her, there was an inability to distinguish the spiritual ramblings with other languages her mother used to communicate with her. The mother's attempt at revelation, though scarce, was regarded by Beccah as one of her out-of- 
the-world ramblings. Failing to identify with the fact that the "frail, wild-haired lady with pajamas throwing a handful of pebbles into the crowd" (Keller, 1997, p. 87) was her mother, Beccah remained for the most part, an outsider to her mother's life.

Unable to see beyond the physical and the mundane, Beccah's sense of the 'truth' was muted. "I'm teaching you something very important about life", Akiko says as she tries to pass on the spiritual dimension with its masked messages to Beccah who failed to see the significance. In Beccah and her mother's unique relationship, Keller posed the conflict between the reality of the unseen/silenced and intangible versus the seen/spoken and tangible with the scales tipping in favour of the former.

Comfort Woman is about the training Beccah underwent before she finally was able to really know her mother and the significance of her ramblings. Though she thought her mother was insane, she had to proclaim the contrary - "She's not crazy" (Keller, 1997, p. 7). Her proclamation was intended to silence the 'truth' she thought she knew. The distinction between truth/ untruth, normal/abnormal, fantasy/reality, sanity/insanity was obscured by Beccah's inability to comprehend exactly who her mother was as a result of her traumatic and shameful past.

The multiple narrations of Soon Hyo and Beccah in the novel reveal the fragmentation of the relationship between mother and daughter as the "mother's secrets, madness, and lies" are "powerful metaphors for the consequences of Japan's (and subsequently the United States') control and occupation of Korea" (Duncan, 2004, p. 183). Beccah was temporally and emotionally detached from her mother's traumatic experiences although her molestation by her father provided a glimpse of the horror her mother must have endured in the comfort camps. Until the death of Soon Hyo, Soon Hyo and Beccah were culturally 'other' to each other, separated by their different versions of history. Though their stories are intricately interconnected, they are presented as opposing perspectives between daughter and mother written in the first-person narrative, which projects sentiments of isolation and alienation of both mother and daughter. Akiko's isolation was caused by her traumatic past which was too shameful to be spoken except through alternative discourse in her trances. Beccah's isolation was caused by her lack of understanding of her mother's strange behaviour which caused her to label her mother "insane".

The line between 'truth'/fiction was erased as Akiko constantly obfuscated and mute reality by offering alternate versions to her stories. During the moments when Akiko communicated the "truth", it was subjected to Beccah's unreliable interpretation. Beccah's struggle to reconcile what she knew of her mother (the explicit/spoken/ demonstrated) and what was unknown (the hidden/masked/silenced) formed much of the trajectory of the novel.

The struggle of Beccah, to "start imagining” (Keller, 1997, p. 26) her mother's life resonated the challenge Keller posed to her readers to imagine the comfort women's 
lives as she reconstructed their memories. While mother-daughter relationship was fraught with differences and marked by a distinct sense of otherness, the discovery of Beccah at the end of her mother's tragic past formed the gel that fused mother and daughter across distinct boundaries of which had once alienated them from each other. The extraordinary journey of Beccah to understand her mother through her strange articulations, a journey which was fraught with confusion, anxiety and fear was a journey that Keller invited her readers to undertake in Comfort Woman.

Comfort Woman thrives on conflicting parallels and paradoxes, blurring of differences between opposing ideas and concepts. Established ideas/concepts and Korean myths are rewritten in order to inscribe new meanings onto women and their national subjectivity. Keller's narrative techniques problematize and reconciles normally conflicting and opposing concepts such as death and life, spiritual and physical, articulation and silences, sanity and madness, the fantasized and the real, the normal and the abnormal or paranormal, man and woman, woman and woman relationship, purity/holiness and lust, the rapist soldiers and the religious missionaries. Keller constantly juggled the paradoxical positions of exposing and obscuring, muting and telling, in order to create a tension between the real and the unreal, the normal and the abnormal and juxtaposed them in order to abolish the binaric opposites between them to challenge the meaning of gender and nation.
Keller first blurred the lines between madness and sanity in the case of Induk. "Induk didn't go crazy. She was going sane. She was planning her escape" (Keller, 1997, p. 21). Unable to bear the endless rapes in the comfort camp, Induk, one of the comfort women "cracked", snapped out of her silent existence and would not stop talking, "yelling at them to stop their invasion of her country and her body". She reclaimed her identity and her nationality by shouting "I am Korea, I am a woman, I am alive. I am seventeen, I had a family just like you do, I am a daughter, I am a sister" (Keller, 1997, p. 20), finally ending her life by taunting the soldiers till they killed her, paraded her body, "skewered from her vagina to her mouth, like a pig ready for roasting" (Keller, 1997, pp. 20-21).

While Soon Hyo was truly 'free' when she abandoned the encumbrance of her abused body and shift to the spirit realm, Beccah ironically pleaded with the spirit of her dead father to free her mother from the "vengeful ghosts" (Keller, 1997, p. 12) that were holding her captive, demonstrating the extremely limited knowledge Beccah had of her mother's past. Beccah failed to understand that it was only through connection with the spirit world that her mother could escape from the demons of this life. The grip of the 'demons' was what released her from the reality of her unspeakable experiences as comfort woman as her erased identity was only found in her connection with the spirit world. She was herself only when she was with the spirits, for the unendurable pain and agony of the 
comfort camps could only be 'forgotten' when she entered another dimension - a spiritual one.

Akiko's past and her loss of agency and subjectivity were too intangible for Beccah to connect with. The many mutual misconceptions and misunderstandings typical of mother-daughter relationships made Akiko's communication of traumatic experiences to Beccah even more difficult. What Akiko recounted was always either untruths or half-truths.

Songs of wailing and lamentations mask Akiko's past agony. Her expressions of agony were disguised in the form of songs consisting of "long wails of complaints and demands and wishes for the dead" (Keller, 1997 , p. 27). Beccah's hope of singing 'Rudolph the Red-Nosed Reindeer' at the school's Xmas Xtravanganza (Keller, 1997) was in opposition to her mother's wailings as Keller enhanced the sense of irony by juxtaposing the mother's dark secret with Beccah's childish glee and hope. Similarly, Beccah's embarrassment at her mother's 'insanity' signified a denial of her own 'Koreanness" as "[t]he very fact that Beccah thinks her mother is insane gestures to a lack of cultural knowledge that would give her the hermeneutic tools to make sense of Akiko's behaviour" (Chen, 2005, p. 120). Ironically, she said "You're not yourself" (Keller, 1997, p. 12), not knowing that Soon Hyo was most herself when she's 'insane' to others; she was in the process of reclaiming her self-identity, albeit a different one from the one she had lost.
The web of silencing was reinforced between mother and daughter as Akiko's connection to reality was severed by the extreme violence she had endured. Beccah had to mask her mother's past by her own make-belief stories that her parents had met when her mother was a famous singer in Korea. The absent truth was replaced by stories conjured up from her own favourite movies to fill in the gaps as stories and fantasies were juxtaposed with the feeling that there was a reality somewhere that Beccah could not seem to access. What's the truth? Unknown to her, this was the pertinent question she would ask for the rest of her adult life until she could undo the silences, and interpreted the messages concealed in her mother's chantings, wailings and songs. Beccah had to re-imagine the past when the mother's stories constantly changed, contradicting previous tales. The "truth" was elusive, subjective and fragmented to Beccah through much of the novel and the "truth" remained her quest until her mother's death.

In Beccah's fantasy, her father was her saviour, saving her and her mother from Korean ghosts and demons. Just like her mother's life and her past, the 'actual man' her father was vague to Beccah, dimmed by 'smoke and ash' from the Monopoly money and paper-doll clothes. The ceremonies for Beccah's father demonstrated a rejection of Western culture and the continuation of traditional cultural practice as Soon Hyo/ Akiko continued to re-inscribe Koreanness onto Beccah, ensuring her culture lives on. 
Perhaps the ultimate insult and humiliation was the Monopoly money, paper-doll clothes and offering of food to the dead appear stark and in contrast to what the man, the Christian missionary was and represented. That he was accorded a Confucian honour though he was a Christian missionary signified the taking over of his identity and control. The rendering of Taoist rituals in 'honour' of her Christian missionary husband resulting in the masking of his memory and identity was Akiko's way of exacting revenge on patriarchy, symbolizing an erasure of patriarchal identity and colonialism.

Sexuality is often the vehicle of oppression as the commodification of the female body for rape and sexual abuse implies the eradication of the victim's subjectivity and individuality. In Comfort Woman, the women are nameless and replaceable commodities. Soon Hyo was named Akiko 4, after the comfort woman whose identity and stall in the camps she replaced, and once her virginity was auctioned off to the highest bidding soldier, she became a "free for all" (Keller, 1997, p. 21).

Akiko's ultimate victory over patriarchy and colonialism was symbolized in the death of her husband which she took credit for: "I wished him to death ... Every day I think, every day I pray, 'Die, die', sending him death-wish arrows, until one day my prayers were answered" (Keller, 1997, p. 12). This achievement by Akiko/Soon Hyo spoke of resistance of patriarchy, colonialism and enactment of nationalism.
Soon Hyo's and Beccah's narrative perspectives are located ambiguously between the intersections of Asia and America, East and West. The motherdaughter relationship becomes the site at which Korean spirituality and superstition clashes with American rationality. Unknown to Beccah, Soon Hyo was her link to the ancient world of her ancestors in Korea. Schultermandl (2007) pointed out that the topic they were most reluctant to talk about the sexual abuses they went through becomes "a basis of mutual identification" (p. 85). The mother-daughter relationship oscillated between identification and alienation as both narrative perspectives offer controversial, opposing ideas with regard to women's sexuality and its reconstruction. Beccah considered her mother weird and unable to integrate into American society and seek to distance herself from the image of womanhood that her mother conveyed in relation to mainstream American culture. Nor do the two women talked about Beccah's sexual molestation by her father which were merely hinted at and obscured by the blurring of Beccah's memories.

The novel treats Beccah's experience of sexual abuse by her father as unspeakable in the sense that Keller did not write about it openly. She depicted Beccah's experience through a recurring nightmare:

But when he rolled me into the sweater, binding my arms behind me, my father opened his eyes not on the demons but in me. And the blue light from his eyes grew so 
bright it burned me, each night, into nothingness. (Keller, 1997, p. 2).

The intertextuality of the sets of firstperson narratives, however, amplifies the hidden message of Beccah's own experience of sexual abuse and thus connects her to the experience of the comfort women. It is only after Akiko's death that Beccah learns about the origin of her mother's trauma and her unorthodox behaviour, such as her fits of melancholy and anger in which her trauma continues to manifest itself.

The valences of speaking and silences are shown in the relationship between the silent and unspoken history of Soon Hyo's life and her Americanized daughter. After six years as a writer of obituaries, words are mere "words and statistics that need to be typed into the system" (Keller, 1997, p. 26). The production of words is cold and clinical, matter-of-fact, devoid of all feelings and sentiments - "count how many inches" to fill, "computing how many names and death dates" to be processed and records of death are merely formulae "templated" in the brain. Her mother's life is more than "name, age, date of birth, survivors, services" (Keller, 1997, p. 26). Language is inadequate to describe the depths and layers of her mother's life and deaths as Soon Hyo concealed and erased her unspeakable past so well that Beccah felt that "it did not occur to me that my mother had a life before me" (Keller, 1997, p. 26). As she wrote of other people's death, she was unaware of the meanings of her mother's multiple deaths and her multiples selves and identities.

\section{Silences as Subversive Strategy}

Comfort Woman inquires into the links between languages and silences and subjectivity, colonial domination and Korean nationalism, sexuality and nation, resisting any attempts at separating the links. By presenting a deranged character who speaks a paranormal language which requires utmost attention, or rather inattention to the normal in order to ascend a higher, spiritual plane in order to comprehend. Keller appeals to the world to pay attention to their silences, and 'stop concentrating' on their articulation.

Keller represented the female body as unmistakably political and public because it was determined and defined by sexism and colonialism. The renaming of the women to Japanese names symbolizes not only colonial domination and suppression of differences, but objectifies the women as replaceable and thus "renamable", dictated to by commands of "close mouth" and "open legs" (Keller, 1997, p. 16). From the silencing at the comfort camp where the comfort women were only taught enough words to service the soldiers and not expected to understand and were forbidden to speak any language at all, to her silent existence at the missionaries, Akiko had shown triumph over language by capitalizing on silence as an effective discourse, ranging from "eye movements, body posture, tilts of head" or "rhythmic rustlings between our stalls” (Keller, 1997, p. 16). 
Having been given a new identity as Akiko, and violated as comfort woman Soon Hyo had to re-invent herself, spoke a new language, which was the language of silence at first. Comfort women were treated as tools for the soldiers to use, degraded to inanimate objects. They were dehumanized in order to make inhumane treatment acceptable, and these women accepted this idea of their inanimate selves in order to cope with the ordeal. Akiko had flown out of her body and her life, escaped from herself and entered into the world of the spiritual and the intangible. Her life, like her language, is no longer intelligible on the normal realm. In this physical realm which her daughter and others belong, Akiko is silent, not because she is not speaking; but her chosen discourse becomes her empowering tool.

Cheung (1993) argued that silence itself could also be subversive rhetorical strategy for agency. Throughout the novel, Keller characterized language as consisting of both articulation and silences. Just as the desire to speak is a subversive act against sexual oppression, so is the resolution to maintain silence. Both Akiko's articulations of the abuse the comfort women underwent in the comfort camps and her narratives of her own abuse and her silences towards her daughter serve in the novel as empowering tools of resistance and deconstruction of ideas related to women's sexuality. Language in the form of articulation and silences is paradoxically employed both as a bridge of cross-cultural connection and as an obstacle between Beccah and her mother. It is only upon her death, when Beccah learns to transcend the physical and enter into the spiritual that she is able to unravel her mother's mysteries, thus "un-silencing" her. Ironically, it is only when Beccah "stopped concentrating" that she realized that her mother was "singing words, calling out words, telling a story" (Keller, 1997, p. 191).

Scorning "normal” and earthly languages, Akiko learnt languages of touch and spiritual language. Akiko tried to save her daughter from being dictated and defined by language. She touched each part of her body so that "she knows that all of what I touch is hers and hers to name in her own mind" (Keller, 1997, p. 22) as naming is a way of domination and control just as she was named 'Akiko' by the Japanese soldiers and "Mary" by the Christian missionaries. By teaching her daughter to name parts of her body before "language dissects her into pieces that can be swallowed and digested by others not herself" (Keller, 1997, p. 22), Akiko is giving the keys of the power of language and silences to her daughter. To Akiko, language has the ability to destroy, to dissect her daughter "into pieces" (Keller, 1997, p. 22) and she passes on to Beccah the language of silence which Soon Hyo recognizes as the only "true" language which consists of silent alertness, attentiveness. It is through her alert silences that she communicates with Beccah: "I watch her with a mother's eye, trying to see what she needs - my breast, a new diaper, a kiss, her toy - before she cries, before she has to give voice to her pain" (Keller, 1997, p. 21). 
Keller's interrogation of the reliability of language informs my reading and investigation of the way she complicated the symbol and meanings of women's sexual bodies to a colonized nation by demonstrating the resourcefulness of Akiko in keeping silent and appropriating silence. The 'language' that was enforced in the comfort camps is working for Akiko when she was rescued and brought to the missionaries. During her stay with the missionaries, Akiko had encased herself in a world of silence as she watched the missionaries' chattering mouths but could not make out what they were saying (Keller, 1997, p. 63), similar to the comfort camps when she had understood very little of what the Japanese soldiers were saying. As much as she was silenced in the camps, she was silencing herself, thinking that as long as she was quiet, she would be overlooked and "allowed to die in darkness" (Keller, 1997, p. 65). Akiko's outer silence was in contrast to the sounds at the comfort camp that she could not shut out from her mind - the sounds of women crying, Japanese soldiers laughing, grinding of trucks delivering more soldiers. Akiko's silence was not understood by the missionaries but the reader, who has access to her mind, understands that her outer silence was as potent as the noises she keeps hearing within.

Shocking parallels are drawn between the comfort camp and the missionaries' place not only to evoke the poignant reality that she is again given over, sold, betrayed and abused over and over again but more significantly, to fuse religious intentions and military aggression. The women's sleeping quarters are compared to the stalls at the comfort camps as "not much bigger", drawing a parallel between two seemingly dichotomous places.

The 'holy' missionaries are equated with the lustful soldiers as Keller paraded two contrasting ideas and drew a parallel between them. The sound of the missionary slapping on the pulpit was associated with "the sounds of women's naked buttocks being slapped as they paraded in front of new arrival of troops" (Keller, 1997, p. 70). The double speak of Soon Hyo's recollection cannot be ignored: "(a)s the missionaries pulled at my hair, my clothes, my arms ... I turned my eyes away and gave my body to them" (Keller, 1997, p. 63). Although the close identification with the comfort camps speaks of the extreme extent of Akiko's haunted memories, this sharp association is also Keller's way of critiquing and equating the ways the Western world spreads their gospel, culture, philosophy to the Eastern world as similar to the rapes that took place in the comfort camps by the Japanese during World War II.

Akiko's silence did not fail to attract the missionary to her who sees in her the exciting Eastern exoticism and mystery, misinterpreting her silences as submission and meekness. Keller's technique results in a clear display of the missionary's lust. The urge of the minister - "Just give yourself to Him" is a sexual pun as his reference to himself and God is interchangeable and he likens himself to God - "do not forsake me or the one true God" (Keller, 1997, p. 
94). "Trust in Him. And me", he pleaded. "Please Akiko, welcome the Lord - and me - we who wait for you with open arms." Such doublespeak, using the name of God is personified to oppress, mislead and coerce, is a form of masking of evil intentions as he desperately tries to exert sexual control over her, ironically in the name of God, "searching for words that would split open" her silence (Keller, 1997, p. 94), which is a form of pun for sexual conquest. Akiko could see through the intentions behind those words, recognizing the lust in his "hooded eyes, in his breathing, sharp and fast, in the way his hands fluttered about his sides as if they wanted to fly up against my half-starved girl's body with its narrow hips and new breasts" (Keller, 1997, p. 95). The missionary is comparable to the Japanese soldiers who had raped her without speaking and prohibited her to speak.

With descriptions that carry strong connotation of sexual slavery, similar to the violence she had experienced at the comfort camps, Akiko's baptism was carried out in the name of God: she was pulled "by the hand and the hair" (Keller, 1997, p. 103) and "(w)et up to the chest, one hand clutching my hair, he delivered me unto the Lord" (Keller, 1997, p. 103). The lustful desire of the Christian minister for her was masked by proclamation of noble intentions as he claimed that "this girl ... has no place to go, no one to guide her ... God is giving me a chance to save her, to guide her into the flock by yoking her to its shepherd" (Keller, 1997, p. 101). The white dress given to her by one of the missionary ladies because she was "going to be reborn in the Spirit" (Keller,
1997, p. 102) and to be married symbolizes purity which was ironical in Akiko's case. What the Christian missionaries did not see but given privy to the readers was that Akiko had "died" and had been reborn in a very different sense.

Akiko's initiation into her roles as wife and Christian was narrated in a way which likens it to initiation into bondage/slavery, full of connotation of sexual violence. There were hints that he had coveted the mysterious Eastern exoticism in her. For instance, on their wedding night: "It is better to marry than to burn, he whispered, and I am burning for you. There is something about you - the way you look so innocent, yet act so experienced - that makes me on fire for you." (Keller, 1997, p. 106)

The first sexual act with "the minister husband" was heavily suggestive of a lamb led to a slaughter house. He assumed she had had no experience and proceeded to tell her about pain and bleeding the first time. Her silence conceals her thoughts that she "knew what it felt like to stretch open for many men ... about blood with the first and with the hundredth, and about pain sharp enough to cut your body from your mind" (Keller, 1997, p. 106). "Don't worry sweetie, my little lamb. I will be gentle", "he said, - then he bit my neck" (Keller, 1997, p. 106, emphasis mine). The metaphor of the deceptive wolf devouring a helpless lamb enhances the effect of this patriarchal masking and disguise. The implication of marital rape is enhanced through metaphors and parallels as the husband's body is equated to the "bodies of innumerable men" (Keller, 1997, p. 106). 
Akiko goes through the rituals she needed to survive or to feed the perception of accommodating but in the end, in secret, and in her appropriated silences, she remains unconverted. Akiko's performative acts of being silent like a lamb become an act of defiant empowerment. In the "darkest part of the night", it is not to the Christian God, or any other gods, but to Induk whom she calls out to. Her silences empower and contain her secret communion with her woman lover, Induk. The silent compliant of the outside is countered inwardly with her communion with Induk as she prays and pines for Induk to return to her (Keller, 1997, p. 92). Akiko's prayers are subversive performances; performed to re-inscribe what had been inscribed onto her body and identity. Her by now strategic silences are enhanced by chantings of Induk's name. While her oppressor/protector lusts after her, she shuts out the patriarchal world and the world of imperialism by pining after and aligning with Induk, who is not only Korean but as she declared before dying, Korea itself.

Even as her silences can be interpreted as passivity and signifying consent, gradually, Akiko's empowerment is achieved through appropriating the performative silences which becomes her lethal weapon. Her "passivity" becomes a triumphant performance in the scene when her husband was eventually driven to his knees as his commands for her to fulfil her role as wife were only met with stubborn silences as he resorts to beg, "Please, please, at least help me tidy up" (Keller, 1997, p. 112).

\section{CONCLUSION}

\section{Rewriting the Feminine Construction of a Nation}

Keller in Comfort Woman demonstrated resistance to humiliating perception with regard to Korean women's sexuality through the main Korean women figures in Comfort Woman - Induk and Soon Hyo who resisted male-defined definition of a nation and the feminization of a nation, and re-invented ideas and concepts of Korean national identity through various subversive techniques. In Comfort Woman, women's sexuality is reconstructed - disrupting conventional, male-centred narratives through employment of tropes that are ethnic-specific to re-write the meanings of women as subjects and national heroines.

Through the deployment of heroic women as national subjects, Keller contested the feminization of Korea and rewrote the feminine construction of a nation. Resistance is shown through Induk, by proclaiming aloud her identity as not merely a Korean, but Korea itself and Soon Hyo, by aligning her soul and body with that of Induk, that is, Korea (Duncan, 2004). Keller re-wrote the feminine construction of a colonized nation by creating women characters who represented not feminization of a colonized nation but who proclaimed themselves as the nation itself, transcending the perception of women as commodities to be looted or to be protected against looting. Keller's narrative effectively posed a challenge to and revised patriarchal definition and notion of the meaning of a nation. 


\section{ACKNOWLEDGEMENT}

I would like to thank the School of Distance

Education, Universiti Sains Malaysia, Penang for all forms of support and encouragement rendered. I thank reviewers and journal officers of Pertanika JSSH for insights and comments that have helped improved this article.

\section{REFERENCES}

Chen, T. (2005). Double agency: Acts of impersonation in Asian American literature and culture. Stanford, USA: Stanford University Press.

Cheung, K.-K. (1993). Articulate silences: Hisaye Yamamoto, Maxine Hong Kingston, Joy Kogawa. Ithaca, USA: Cornell University Press.

Duncan, P. (2004). Tell this silence: Asian American women writers and the politics of speech. Iowa City, USA: University of Iowa Press.

Keller, N. O. (1997). Comfort woman. New York, USA: Penguin.
Kim, H. S. (1997). History and memory: The "Comfort Women" Controversy. Positions 5(1), 74-106.

Schultermandl, S. (2007). Writing rape, trauma, and transnationality onto the female body. Meridians: Feminism, Race, Transnationalism, 7(2), 71-100.

Soh, S. C. (2008). The comfort women: Sexual violence and postcolonial memory in Korea and Japan. Chicago, USA: The University of Chicago Press.

Yang, H. (1997). Revisiting the issue of Korean "military comfort women": The question of truth and positionality. Positions, 1(1), 52-71.

Yang, H. (1998). Re-membering the Korean military comfort women: Nationalism, sexuality, and silencing. In E. H. Kim \& C. Choi (Eds.), Dangerous women: Gender and Korean nationalism (pp. 123-140). New York, USA and London, England: Routledge. 